\title{
Short-term physiological responses to copper stress in Salvinia auriculata Aubl.
}

\author{
Respostas fisiológicas de curta exposição ao estresse por cobre \\ em Salvinia auriculata Aubl.
}

Andresa Lana Thomé Bizzo ${ }^{1}$, Aline Chaves Intorne ${ }^{2}$, Pollyana Honório Gomes ${ }^{1}$,

\author{
Marina Satika Suzuki ${ }^{1}$ and Bruno dos Santos Esteves ${ }^{1}$
}

${ }^{1}$ Laboratório de Ciências Ambientais, Centro de Biociências e Biotecnologia, Universidade Estadual do Norte Fluminense Darcy Ribeiro - UENF, Av. Alberto Lamego, 2000, Parque Califórnia, CEP 28013-602, Campos dos Goytacazes, RJ, Brazil e-mail: dresa_bizzo@yahoo.com.br; pollyanagomes10@hotmail.com; marina@uenf.br; brunosnts@yahoo.com.br

${ }^{2}$ Laboratório de Fisiologia e Bioquímica de Microrganismos, Centro de Biociências e Biotecnologia, Universidade Estadual do Norte Fluminense Darcy Ribeiro - UENF, Av. Alberto Lamego, 2000, Parque Califórnia, CEP 28013-602, Campos dos Goytacazes, RJ, Brazil e-mail: aline_intorne@yahoo.com.br

\begin{abstract}
Aim: To evaluate, in a short-time exposure, the physiological responses of Salvinia auriculata Aubl. under different concentrations of $\mathrm{Cu}$. Methods: The plants were exposed to treatments with $0.01,0.1,1$ and $10 \mathrm{mM}$ of $\mathrm{Cu}$ in a period of 2 days. Then development variables of $S$. auriculata (weight, photosynthetic pigments, and soluble carbohydrate), lipid peroxidation (malondialdehyde, aldehydes, and electrolyte leakage) and production of antioxidants (anthocyanins, carotenoids, flavonoids, and proline) were evaluated. Results: It was observed fresh weight reductions in concentrations above $1 \mathrm{mM}$ of $\mathrm{Cu}$. Chlorophyll $a$ decreased with the increase of $\mathrm{Cu}$ concentrations unlike chlorophyll $b$. The ratio chlorophyll $a$ / chlorophyll $b$ was changed due to the degradation of photosynthetic pigments. The reductions of carotenoids were more pronounced than that of total chlorophyll. The values of electrolyte leakage ranged from 14 to $82 \%$ and lipid peroxidation from 7 to $46 \mathrm{nmol}^{-\mathrm{g}^{-1}}$. Flavonoids and soluble carbohydrates showed reductions with the increase of $\mathrm{Cu}$ concentration. Anthocyanins, phenolic compounds, and proline when subjected to $0.1 \mathrm{mM}$ of $\mathrm{Cu}$ had increased, suggesting adaptability of plant stress caused directly by metal and reactive oxygen species. In higher concentrations, degradation and/or direct modifications of these molecules possibly occurred. Conclusions: The data suggest that $S$. auriculata is provided with an efficient mechanism against stress caused by $\mathrm{Cu}$ in the concentration of $0.1 \mathrm{mM}$. As for higher concentrations ( 1 and $10 \mathrm{mM}$ ), despite its role as micronutrients, $\mathrm{Cu}$ was toxic to the plant due to the redox behavior of this metal, which leads to the exacerbated formation of reactive oxygen species, inducing to severe damage such as biological membrane degradation and protein denaturation.
\end{abstract}

Keywords: lipid peroxidation, antioxidant, proline, metal stress.

Resumo: Objetivo: avaliar em curto tempo de exposição às respostas fisiológicas de Salvinia auriculata Aubl. sob diferentes concentraçôes de $\mathrm{Cu}$. Métodos: as plantas foram expostas a tratamentos com 0,0;0,01;0,1; 1 e $10 \mathrm{mM}$ de $\mathrm{Cu}$ em um período de 2 dias. Em seguida foram avaliadas variáveis de desenvolvimento de $S$. auriculata (peso, pigmentos fotossintéticos e carboidratos solúveis), peroxidação lipídica (malonaldeído, aldeídos e extravasamento de eletrólitos) e produção de antioxidantes (antocianinas, carotenóides, flavonóides e prolina). Resultados: Foram verificadas reduçôes das massas frescas nas concentraçóes acima de $1 \mathrm{mM}$ de $\mathrm{Cu}$. A clorofila $a$ reduziu com o aumento da concentração de $\mathrm{Cu}$, diferentemente da clorofila $b$. A razáo clorofila $a /$ clorofila $b$ foi alterada, devido à degradação dos pigmentos fotossintéticos. As reduçóes dos carotenóides foram mais acentuada do que a de clorofila total. Os valores de extravasamento de eletrólitos variaram de 14 a 82 \% e peroxidação lipídica de 7 a 46 nmol.g ${ }^{-1}$. Flavonóides e carboidratos solúveis mostraram reduçóes com o aumento da concentraçáo de $\mathrm{Cu}$. Antocianinas, compostos fenólicos e prolina quando submetidas a $0.1 \mathrm{mM}$ de $\mathrm{Cu}$ apresentaram aumento, sugerindo adaptabilidade da planta ao estresse causado diretamente pelo metal e espécies reativas 
de oxigênio. Nas concentrações superiores, possivelmente, ocorreram degradação e/ou modificaçóes diretas destas moléculas. Conclusóes: Os dados sugerem que $S$. auriculata é provida de um mecanismo eficiente contra estresse causado por $\mathrm{Cu}$ na concentração de $0.1 \mathrm{mM}$. Já nas concentraçóes mais elevadas (1 e $10 \mathrm{mM}$ ), apesar de seu papel como micronutriente, $\mathrm{Cu}$ foi tóxico para a planta devido ao comportamento redox deste metal, que leva à formação exacerbada de espécies reativas de oxigênio, induzindo danos severos como degradação de membranas biológicas e desnaturação protéica.

Palavras-chave: peroxidação lipídica, antioxidante, prolina, estresse metal.

\section{Introduction}

$\mathrm{Cu}$ is an essential micronutrient that is toxic to the plants at high concentration (Brown and Rattigan, 1979). This element can be found naturally in water bodies (Delmail et al., 2011) up to a maximum value of $0.009 \mathrm{mg} \mathrm{L}^{-1}(\cong 0.141 \mu \mathrm{M})$ for freshwater according to Resolution 357/05 of the National Council for the Environment in the Brazil - CONAMA (Brasil, 2005). Though, this metal is between one of the most frequently discharged elements into the environment (Moore, 2011).

Among the factors that contribute most to the increase of $\mathrm{Cu}$ in the aquatic environment is urban manipulation (algae control in swimming pools and aquariums), agricultural (pesticides) and industrial (batteries and electroplating) (Guida et al., 2008; Song et al., 2011). Excessive intake of this metal in water can threaten human health through the consumption of aquatic organisms and the water itself (Hu et al., 2007). Because of this, the United States Environmental Protection Agency (USEPA) lists the $\mathrm{Cu}$ as a priority pollutant (Salomons et al., 1995).

Plants that inhabit locations with high concentrations of metals in water have mechanisms to tolerate and/or resist toxicity of these elements (Hanikenne and Nouet, 2011). The excess metal can induce many changes in plant metabolism, such as ionic imbalance, changes in photosynthetic and respiratory enzymes as well as formation of complex with substances such as amino acids and phenolic compounds (Sharma et al., 1998; Yruela, 2005).

Commonly, the heavy metals attack the biological membranes, causing changes in the permeability and selectivity of these structures (Solanki and Dhankhar, 2011). These changes may relate to the direct action of the metal or reactive oxygen species (ROS). ROS production occurs continuously in varied organelles, and when plants are exposed to high concentrations of this metal, there is an increase in this production (Gratão et al., 2005). $\mathrm{Cu}$ is a metal redox, which can catalyze the formation of ROS in Haber-Weiss and Fenton reaction types (Banci et al., 2011). These molecules can induce degradation of biological membranes, chlorophyll breakdown, protein denaturation and DNA mutation (Apel and Hirt, 2004). Thus, ROS reaction with fatty acids of biological membranes produces aldehydes (lipid peroxidation), especially malondialdehyde (MDA). This compound is an indicator of oxidative damage, and it can be related to increased permeability of cell membranes under stress conditions.

Some macrophytes have great ability to remove and accumulate various elements and compounds present in water and sediment (Núñez et al., 2011), and they are indicated for maintenance of environmental quality. Salvinia auriculata Aubl. (Salvinaceae) is a floating aquatic macrophyte that has potential for wastewater treatment, due to its high rate of growth in lentic systems that are rich in nitrogen and phosphorus (Nahlik and Mitsch, 2006). This plant has floating leaves with some modified submerged leaves, similar to roots that act by absorbing water and ions (Sculthorpe, 1967).

The genus Salvinia demonstrates ability to accumulate large quantities of metals (Dhir and Srivastava, 2011). However, very little is known about the Salvinia auriculata response to stress by $\mathrm{Cu}$. In studies with Salvinia minima, it was observed that increases in $\mathrm{Cu}$ concentration from

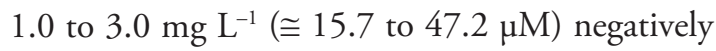
impacted plant growth. However, the reduction in plant growth was not severe enough to inhibit plant growth. The plants demonstrated the ability to accumulate significant concentrations of $\mathrm{Cu}$ in its tissues (Al-Hamdani and Blair, 2004). Thus, the aim of this study was to examine the effect of increasing concentrations of $\mathrm{Cu}(0.01,0.1,1$, and $10 \mathrm{mM})$ in a short time exposure on (i) the development of $S$. auriculata (weight, photosynthetic pigments, and soluble carbohydrate) (ii) lipid peroxidation (MDA, aldehydes, and electrolyte leakage), and (iii) production of antioxidants (anthocyanins, carotenoids, flavonoids, and proline). The data acquired indicate the high tolerance of $S$. auriculata to $\mathrm{Cu}$, suggesting its use in the remediation of polluted water systems. 


\section{Material and Methods}

\subsection{Plant material, growth conditions and metal treatment}

S. auriculata were obtained from uncontaminated aquatic ecosystems around Campos dos Goytacazes, Rio de Janeiro, Brazil between 21 ${ }^{\circ} 43^{\prime} 10.49^{\prime \prime} S$ and $41^{\circ} 19^{\prime} 49.68^{\prime \prime} \mathrm{W}$. The plants were transported to the laboratory within water tanks (20 L). They were thoroughly washed with tap water to remove attached inorganic and organic matter.

S. auriculata were cultured in half-strength Hoagland's solution at $\mathrm{pH} 5.8 \pm 0.1$ without aeration for about 2 months before to start the experiments. The plants were grown under greenhouse conditions in natural sunlight with mean temperature compensated of $27 \pm 2{ }^{\circ} \mathrm{C}$ and relative humidity of $74 \pm 7 \%$. The National Institute of Meteorology (INMET) provided daily data from Meteorological Station of Campos dos Goytacazes in the period of October 2009 to March 2010.

The plants were acclimatized for 7 days before the metal treatment in half-strength Hoagland's solution under laboratory conditions (16:8 h light/ dark cycles at $30 \pm 2{ }^{\circ} \mathrm{C}, 50 \mu \mathrm{mol}$ photons $\mathrm{m}^{-2} \mathrm{~s}^{-1}$ ). Subsequently, $5 \mathrm{~g}$ of plants were placed in $1,000 \mathrm{~mL}$ flasks containing half-strength Hoagland's solution with different concentration of $\mathrm{Cu}$ for $48 \mathrm{~h}$. The solutions were prepared with $\mathrm{CuCl}_{2}$ (Merck) using $0.01,0.1,1$, and $10 \mathrm{mM}$ of $\mathrm{Cu}$. These high concentrations were used to test the ability of the S. auriculata to resist stress caused by $\mathrm{Cu}$. In total, there were nine samples per treatment.

\subsection{Development of Salvinia auriculata Aubl.}

The fresh weight (FW) of plants was measured from each treatment. For determination of dry weight (DW), the samples were oven dried at $70{ }^{\circ} \mathrm{C}$ for $96 \mathrm{~h}$. The plant water content (WC, $\left.\mathrm{mL} \mathrm{g}^{-1} \mathrm{DW}\right)$ was estimated using the equation: $\mathrm{WC}=(\mathrm{FW}-\mathrm{DW}) / \mathrm{DW}$.

The growth rate (GR) was calculated based on the increase in FW over $48 \mathrm{~h}$ and it was expressed in percent. For this analysis, we used the formula: $\mathrm{GR}(\%)=\left(\mathrm{FW}_{\text {final }}-\mathrm{FW}_{\text {initial }}\right) \times 100$.

The photosynthetic pigments (chlorophyll $a, b$, total and carotenoids) were determined according to the method of Wellburn (1994). S. auriculata plants $(50 \mathrm{mg}$ of $\mathrm{FW})$ were placed in plastic test tubes containing $5 \mathrm{~mL}$ dimethylsulfoxide reagent (DMSO) as organic solvent and kept in the dark. After 4 days, the extract was analyzed in a spectrophotometer at $480 \mathrm{~nm}, 649 \mathrm{~nm}$ and $665 \mathrm{~nm}$. The total chlorophyll, chlorophyll $a / b$ and total chlorophyll/carotenoid ratios were calculated. All the laboratory procedures were carried out in a low light environment.

Soluble carbohydrate content was determined according to the method of Dubois et al. (1956) and Robyt and White (1987). A total of $100 \mathrm{mg}$ of fresh tissue was mixed with $1 \mathrm{~mL}$ of methanol $(80 \%)$ at $70{ }^{\circ} \mathrm{C}$ for $30 \mathrm{~min}$. After the mixture had cooled, $1 \mathrm{~mL}$ of the extract was mixed with $1 \mathrm{~mL}$ of phenol ( $5 \%$ ) and $5 \mathrm{~mL}$ of sulfuric acid (95\%). Thus, the plastic test tubes were incubated for $1 \mathrm{~h}$ at room temperature and the absorption was measured at $640 \mathrm{~nm}$. Glucose was used as a standard.

\subsection{Lipid peroxidation}

The lipid peroxidation was measured by determination of malondialdehyde (MDA) (Heath and Packer, 1968) and other five aldehydes (propanal, butanal, hexanal, heptanal and propanal dimethylacetal) (Meirs et al., 1992), which are breakdown products of lipid peroxidation. A total of $100 \mathrm{mg}$ of fresh plant samples was homogenized in $1 \mathrm{~mL}$ of $0.1 \%$ tri-chloroacetic acid (TCA) and centrifuged at $15,700 \mathrm{~g}$ for $15 \mathrm{~min}$ at room temperature. Thus, $1 \mathrm{~mL}$ of the supernatant was vortexed with $3 \mathrm{~mL}$ of $20 \%$ TCA containing $0.5 \%$ 2-thiobarbituric acid (TBA). This solution was heated for $30 \mathrm{~min}$ at $96^{\circ} \mathrm{C}$. The non-specific absorbance of supernatant at $600 \mathrm{~nm}$ was subtracted from the maximum absorbance at $532 \mathrm{~nm}$ for MDA measurement, and for other aldehydes at $455 \mathrm{~nm}$. For the calculation of MDA and other aldehydes, it was used the extinction coefficients (e) $1.55 \times 10^{5}$ $\mathrm{M}^{-1} \mathrm{~cm}^{-1}$ and $0.457 \times 10^{5} \mathrm{M}^{-1} \mathrm{~cm}^{-1}$, respectively.

The electrolyte leakage (EL) was determined as described by Ben Hamed et al. (2007). The plant samples (300 mg of FW) were placed in plastic test tubes containing $15 \mathrm{~mL}$ of ultra-pure water. These tubes were incubated in a water bath at $25^{\circ} \mathrm{C}$ for $3 \mathrm{~h}$ and the initial electrical conductivity (EC) of the medium was measured by an EC meter (Metrhom, Switzerland).Then, the samples were heated for $20 \mathrm{~min}$ at $96^{\circ} \mathrm{C}$ to release all the electrolytes. After the samples were cooled at $25^{\circ} \mathrm{C}$, and the final EC was measured. The EL was calculated by using the formula: $\mathrm{EL}=\left(\mathrm{EC}_{\text {initial }} / \mathrm{EC}_{\text {final }}\right) \times 100$.

\subsection{Antioxidants}

Phenolic compounds were determined according to the method of Soland and Laima (1999). The plant samples (100 mg of FW) were incubated 
with $5 \mathrm{~mL}$ of absolute ethanol at room temperature for $24 \mathrm{~h}$. The extract was mixed with $0.5 \mathrm{~mL}$ of Folin-Ciocalteu's reagent (diluted 1:1 with water) and $1 \mathrm{~mL}$ of $5 \%$ sodium carbonate. The absorbance was measured at $725 \mathrm{~nm}$ after $1 \mathrm{~h}$. Tannic acid was used as a standard.

For determination of anthocyanin content, the plant samples ( $50 \mathrm{mg}$ of $\mathrm{FW}$ ) were placed in $5 \mathrm{~mL}$ of methanol: $\mathrm{HCl}, 99: 1(\mathrm{v} / \mathrm{v})$. The tissues were crushed and kept in the dark at $25^{\circ} \mathrm{C}$ for $24 \mathrm{~h}$. Then, the extract was centrifuged at $15,700 \mathrm{~g}$ for $10 \mathrm{~min}$ at room temperature and the absorbance of the supernatant was measured at $550 \mathrm{~nm}$. To calculate the concentration of anthocyanins was used the extinction coefficient $33,000 \mathrm{~mol}^{-1} \mathrm{~cm}^{-1}$ (Wanger, 1979).

The flavonoids content was determined as described by Krizek et al. (1998). The plant samples $(50 \mathrm{mg}$ of $\mathrm{FW}$ ) were mixed with $5 \mathrm{~mL}$ of ethanol:acetic acid, 99:1 (v/v). Then, the samples were gently boiled for $10 \mathrm{~min}$ in a water bath at $80^{\circ} \mathrm{C}$. The absorbance was measured at 270,300 and $330 \mathrm{~nm}$ using spectrophotometer.

Free proline was determined according to Bates et al. (1973). Plant samples (100 mg of FW) were mixed in $5 \mathrm{~mL}$ of $3 \%(\mathrm{w} / \mathrm{v})$ sulfosalicylic acid and the homogenate was centrifuged at $15,700 \mathrm{~g}$ for $10 \mathrm{~min}$ at room temperature. Then, $1 \mathrm{~mL}$ of mixture was heated at $96^{\circ} \mathrm{C}$ for $1 \mathrm{~h}$ in a water bath together with $1 \mathrm{~mL}$ of acid ninhydrin $(2.5 \%$ ninhydrin and $50 \%$ phosphoric acid) and $1 \mathrm{~mL}$ of glacial acetic acid. After cooling, the reaction was measured at $518 \mathrm{~nm}$. Proline was used as a standard.

\subsection{Sensitivity index}

The sensitivity index (SI) was calculated from the difference between dry matter production of copper-treated plants and the control. It was expressed in percent according to the expression: $\mathrm{SI}_{\mathrm{Cu}}=\left[100 \mathrm{x}\left(\mathrm{DW}_{\mathrm{Cu}}-\mathrm{DW}_{\text {control }}\right)\right] / \mathrm{DW}_{\text {control }}$. This parameter was more negative when the plant was sensitive to copper (Saadallah et al., 2001).

\subsection{Statistical analysis}

All values shown in the figures are expressed as mean \pm standard error. Normal distribution for data was analyzed by D’Agostino \& Pearson omnibus normality test. Data were subjected to a one-way analysis of variance (ANOVA) to confirm the variability of data and validity of results. The Tukey test was performed to determine significant differences between treatments. In the figures, the values are marked with a different letters for the significance level $(p<0.05)$ as compared to the control. Discriminant analysis was used to group treatments based on increasing concentrations of $\mathrm{Cu}$.

\section{Results}

It was found that $0.01 \mathrm{mM}$ of the metal did not affect plant development negatively. The damage began to be observed visually from $0.1 \mathrm{mM}$ (Figure 1). The effects of increasing concentrations of $\mathrm{Cu}$ on physiological parameters in S. auriculata are shown in Table 1. It is found that the increase in concentration of $\mathrm{Cu}$ in the environment led to a reduction in weight, significant $(\mathrm{p}<0.05)$ loss in water content, chlorophyll, carotenoids, phenolic compounds, proline, anthocyanins, flavanoids, and soluble sugars. In contrast, there was an increase $(\mathrm{p}<0.05)$ in MDA levels, aldehydes and electrolyte leakage.

S. auriculata did not survive at high availability of $\mathrm{Cu}$ after $48 \mathrm{~h}$ of experimentation. Thus, the plants were separated by using SI as shown in Figure 2. S. auriculata exposed to $0.01 \mathrm{mM}$ of $\mathrm{Cu}$ showed higher tolerance, and from $0.1 \mathrm{mM}$ on SI decreased with the concentration.

The Figure 3 identifies the physiological parameters simultaneously to group the $\mathrm{Cu}$ treatments with similar responses. Control and $0.01 \mathrm{mM}$ were pooled. The treatments with 1 and $10 \mathrm{mM} \mathrm{Cu}$ also were pooled. The treatment with $0.1 \mathrm{mM} \mathrm{Cu}$ kept isolated.

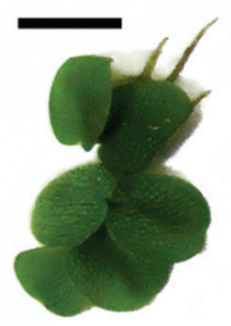

0 mM

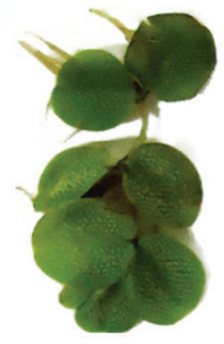

$0.01 \mathrm{mM}$

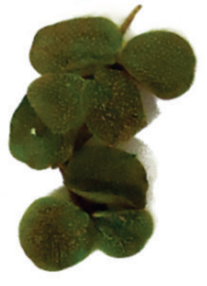

$0.1 \mathrm{mM}$

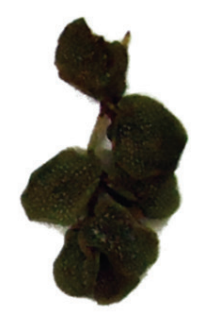

$1 \mathbf{~ m M}$

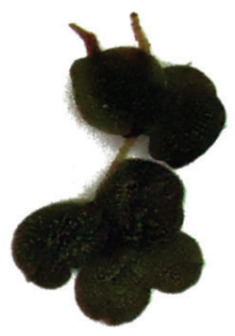

$10 \mathrm{mM}$

Figure 1. Plants of Salvinia auriculata Aubl. exposed to $\mathrm{Cu}$. The horizontal bar equals $1 \mathrm{~cm}$. 


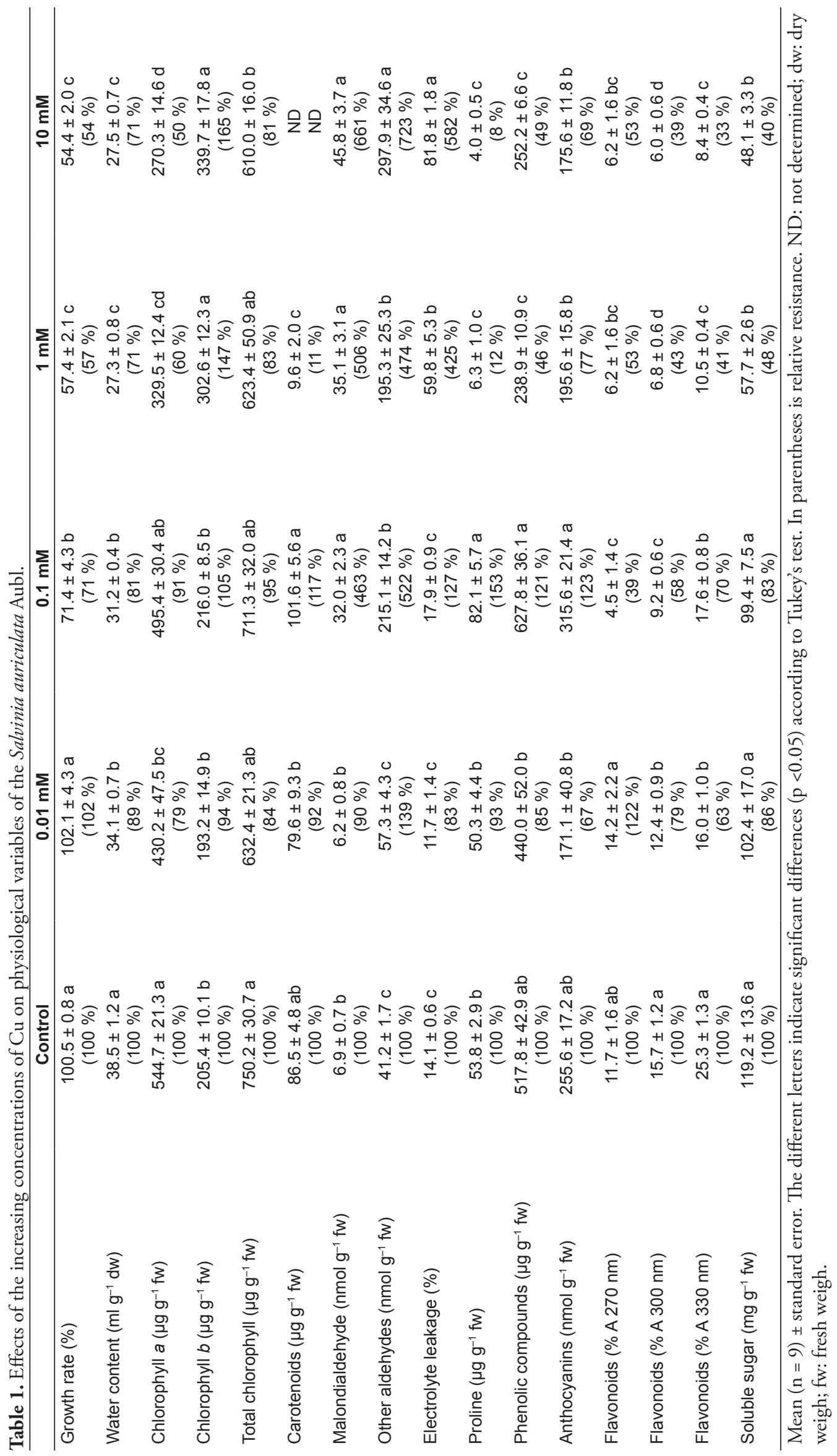




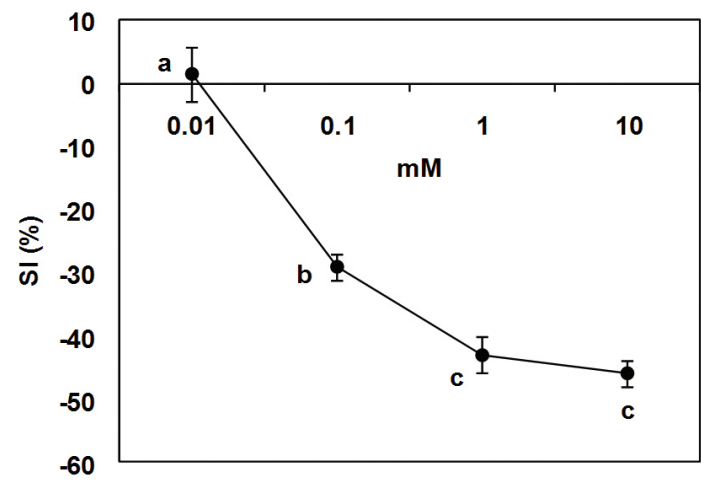

Figure 2. Plant sensitivity index (SI) in Salvinia auriculata Aubl. exposed to increasing concentrations of $\mathrm{Cu}$. The different letters indicate significant differences $(p<0.05)$ according to Tukey's test.

\section{- $0 \mathrm{mM}$ \\ - $0.01 \mathrm{mM}$ \\ - $0.1 \mathrm{mM}$ \\ ○ $1 \mathrm{mM}$ \\ - $10 \mathrm{mM}$}

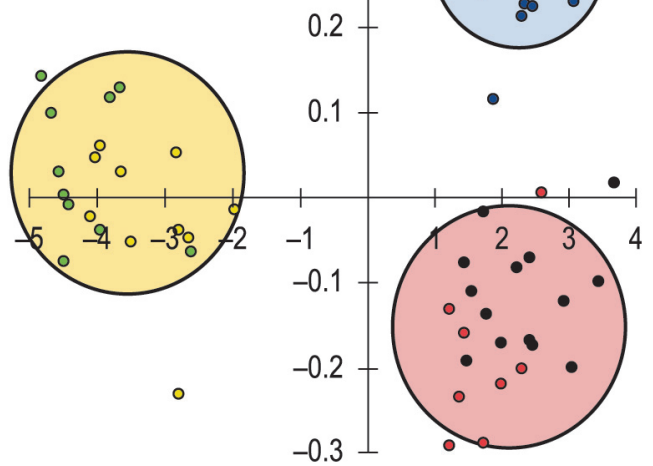

Figure 3. Discriminant analysis of the treatments of $\mathrm{Cu}$ in Salvinia auriculata Aubl.

\section{Discussion}

The availability of heavy metals in the environment showed an increase in the last century due to the increased of anthropogenic activities such as: mining, industrial sewages, and solid waste disposal (Fu and Wang, 2011). Large portion of these contaminants is carried to aquatic ecosystems and strongly affect the organisms that live there. S. auriculata is admittedly an aquatic macrophyte widespread in Neotropical aquatic environments and has a high growth rate. Therefore, it has high potential for uptake of compounds available in the environment (Nahlik and Mitsch, 2006). When evaluating its physiological response to increasing concentrations of $\mathrm{Cu}$, differences were found in the symptoms of toxicity (weight loss and chlorosis) for inducing a variety of metabolic changes that directly contributed to the tolerance to this metal.

During the study, it was observed that responses to the stress in the concentration at $0.01 \mathrm{mM}$ of $\mathrm{Cu}$ in $S$. auriculata have values similar to the control situation. Even occurring damage to the photosynthetic apparatus, it is possible that the synthesis of defensive compounds such as carotenoids, proline and phenolic compounds is energetically more costly, which makes up for living in a stress situation, since there was no increase in antioxidants. This behavior changed when the plants were exposed to $0.1 \mathrm{mM}$ of $\mathrm{Cu}$ concentration. There was energy displacement for the synthesis of defensive compounds to be kept alive, tolerating the stressful condition for $48 \mathrm{~h}$. As for those plants exposed to 1 and $10 \mathrm{mM}$, they presented metabolic breakdown. These data are corroborated by the discriminant analysis.

The weight loss and decrease in the concentration of soluble carbohydrates seem to be directly associated with inhibition of $\mathrm{Cu}$ on cell growth by preventing the plant survival under high concentrations (Alaoui-Sossé et al., 2004). This can be due to enzymatic reactions in carbon fixation, especially in the synthesis and Rubisco activity mediated by the metal (Lidon and Henriques, 1991). In addition, it is noteworthy that the excess $\mathrm{Cu}$ can interact on plastocyanins (transporter of electron) and superoxide dismutase (antioxidant enzyme), affecting the process of photosynthesis and detoxification in chloroplasts (Nouet et al., 2011).

The high concentration of $\mathrm{Cu}$ significantly accelerates the degradation of pigments in $S$. auriculata. The reduction of these pigments probably relates to the increase in reactive oxygen species acquired from the damage of the photosystems $(\mathrm{r}=-0.60, \mathrm{p}<0.05)$. The ionic imbalance caused by excessive $\mathrm{Cu}$ may affect aminolevulinic acid synthesis (precursor of chlorophyll) and replace $\mathrm{Fe}^{2+}$ and $\mathrm{Mg}^{2+}$ in chlorophyll molecules, increasing degradation of the pigments (Stobart et al., 1985). As for the moderate concentrations of $\mathrm{Cu}$ (up to $0.1 \mathrm{mM}$ ), they caused an increase in carotenoids, which protect against stress, since these pigments are responsible for the suppression of singlet oxygen $\left({ }^{1} \mathrm{O}_{2}\right)$, reducing lipid peroxidation and consequent oxidative damage (Juan et al., 2005).

The excess $\mathrm{Cu}$ in the cellular environment causes changes in photosynthetic and respiratory system, intensifying the formation of ROS (Møller et al., 2007). It is known that lipid peroxidation by free radicals induced in the lipid membrane results in a greater oxidative damage mediated by a chain 
reaction. In this study, the accumulation of MDA and other aldehydes was increasing with the highest concentration of $\mathrm{Cu}$ in the environment along with electrolyte leakage $(r=0.76 ; \mathrm{p}<0.05)$, which represents the extent of membrane damage (Bandeoglu et al., 2004). This biological membrane rupture has led to reduction of turgor and, concomitantly, to likely changes in the elasticity of the cell walls (Maksymiec et al., 1995), causing cell death at higher concentrations.

$\mathrm{Cu}$ adverse effects on the metabolism of nitrogen were also observed. The content of proline increased under exposure of $\mathrm{Cu}$ (up to $0.1 \mathrm{mM}$ ), indicating its role in the response to the metal as antioxidant agent (Singh et al., 2010). Moreover, the proline acted as an osmotic regulator, taking part in the stabilization of membranes (Shah and Dubey, 1998) and the formation of non-toxic complex (chelators) with this metal (Rauser, 1999). At 1 and $10 \mathrm{mM}$ concentrations, there was a drastic reduction in the content of proline associated with excess ROS and $\mathrm{Cu}$, which shows that plant defenses were no longer sufficient to respond to the excess metal; and the cell collapsed.
Phenolic compounds responded to stress with decrease in their concentration. However, at 0.1 $\mathrm{mM}$ the values presented a significant increase when compared to the control. Thus, these compounds may be acting as antioxidants (Solecka, 1997; Sakihama et al., 2002), as well as playing the role of chelating agents (Michalak, 2006). The increase observed in the concentration of phenolic compounds is confirmed by the data shown for anthocyanins and carotenoids, which are also compounds formed by aromatic rings. All these molecules along with proline (neutralization of $\mathrm{OH}^{-}$and ${ }^{1} \mathrm{O}_{2}$ ), which presented the same behavior, probably have protective role in plant physiology in response to $\mathrm{Cu}$ stress in different cellular compartments, since anthocyanins are found in the vacuole, carotenoids in the chloroplast as well as proline in the cytosol. The same analysis for flavonoids shows that they were not as effective in acting as antioxidants, since there was not increase in their concentration. In this sense, in the Figure 4, it is proposed a model that it summarizes the physiological changes in $S$. auriculata caused by high levels of $\mathrm{Cu}$.

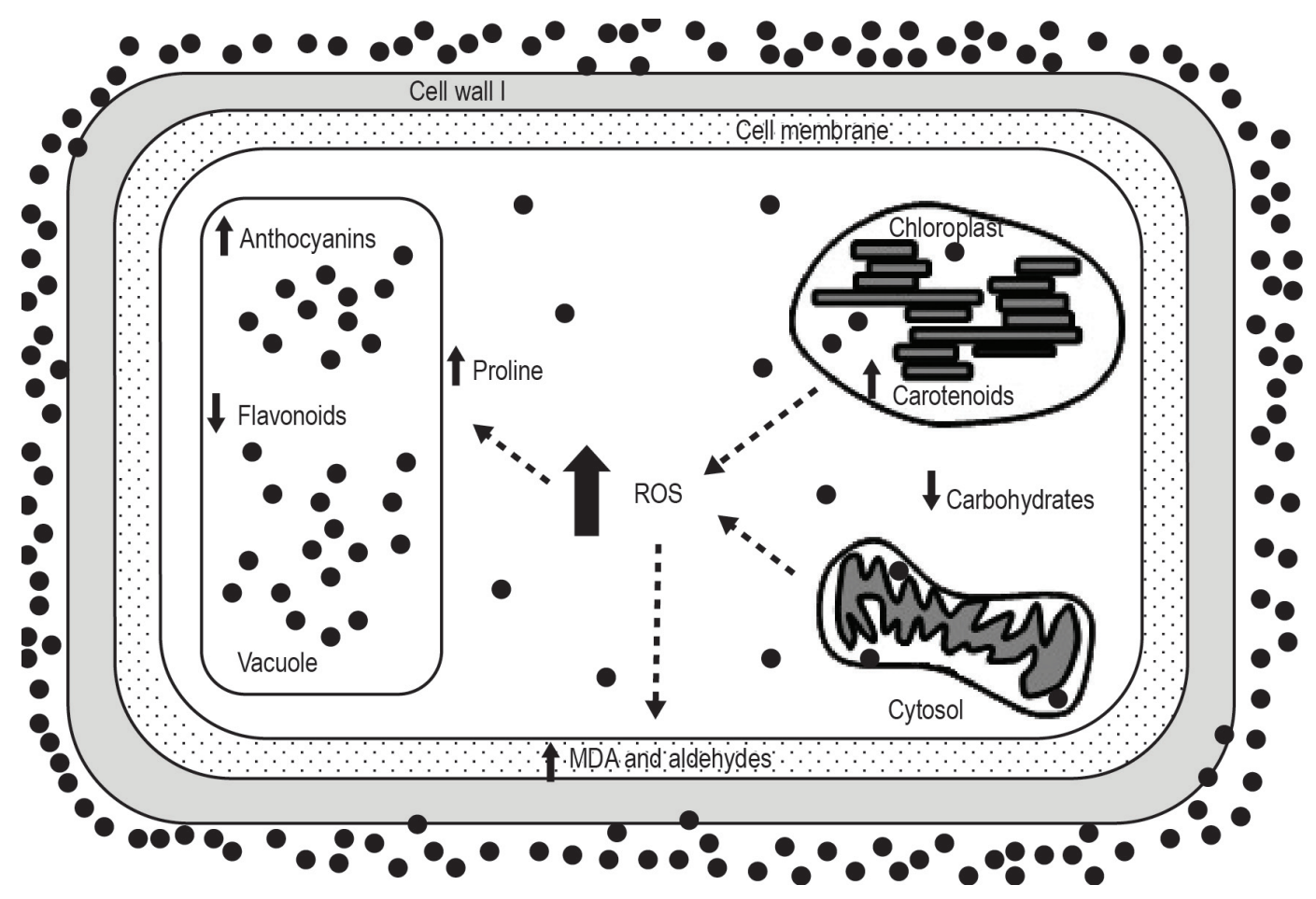

Figure 4. Physiological responses of Salvinia auriculata Aubl. to the addition of $\mathrm{Cu}(\bullet)$. Chloroplast and mitochondria are compartments that produce reactive oxygen species (ROS) continuously. With the increase in the concentration of $\mathrm{Cu}$ in the intracellular environment, disorders occur in these organelles, which increase the production of ROS and affect the synthesis of carbohydrates and flavonoids. This makes the plant cell import $\mathrm{Cu}$ for the vacuole, which is rich in ROS, activating non-enzymatic systems in this organelle (production of anthocyanins and flavonoids) as well as chelators in the cytosol (proline). Carotenoids reduce ROS in the chloroplasts and the anthocyanins act similarly in the vacuole. Added to this, the excess $\mathrm{Cu}$ and ROS affect biological membranes through the degradation of fatty acids causing lipid peroxidation, and consequently the production of the malondialdehyde (MDA) and others aldehydes. 
The concentrations of metal tested in this study were high because our interest was to verify if $S$. auriculata would be a possible candidate for decontamination of environments polluted with $\mathrm{Cu}$ in extreme situations. The results obtained show the high resistance of the aquatic plant to the stress caused by the metal. This, in addition to its high growth rate and ease in harvesting, make it a potential candidate for phytoremediation.

Currently, the use of aquatic macrophytes is under investigation as a viable alternative for remediation of a wide range of contaminants including heavy metals (Hughes et al., 1996; Lee et al., 1998; Rodgers and Bunce, 2001; Miglioranza et al., 2004; Miretzky et al., 2004; Polomski et al., 2009; Augustynowicz et al., 2010; Rahman and Hasegawa, 2011). These researches emphasize that the plant-based approach to remediation of the environments highly contaminated has an interesting cost-effective, because it is cheaper than other methods and safe for human.

\section{Conclusion}

In this study, the results suggest that $S$. auriculata has an efficient mechanism against the stress caused by $\mathrm{Cu}$ at concentrations up to $0.1 \mathrm{mM}$, which is promising for phytoremediation of contaminated aquatic systems. As for higher concentrations (1 and $10 \mathrm{mM}$ ), severe damage was observed along with the exacerbated formation of ROS. Thus, both the metal and ROS induced damage detected in biological membranes and primary sources of energy, leading to cell death of the plant.

\section{Acknowledgments}

The authors wish to thank Valéria Amado for the English corrections. The CAPES, FAPERJ, and UENF supported this research. This paper is a contribution of the Graduate Program of Ecology and Natural Resources of UENF.

\section{References}

AL-HAMDANI, SH. and BLAIR, SL. 2004. Influence of copper on selected physiological responses in Salvinia minima and its potential use in copper remediation. American Fern Journal, vol. 94, no. 1, p. 47-56. http:// dx.doi.org/10.1640/0002-8444(2004)094[0047:IO COSP]2.0.CO;2

ALAOUI-SOSSÉ, B., GENET, P., VINIT-DUNAND, F., TOUSSAINT, ML., EPRON, D. and BADOT, PM. 2004. Effect of copper on growth in cucumber plants (Cucumis sativus) and its relationships with carbohydrate accumulation and changes in ion contents. Plant Science, vol. 166, no. 5, p. 1213-1218. http://dx.doi.org/10.1016/j.plantsci.2003.12.032

APEL, K. and HIRT, H. 2004. Reactive oxygen species: metabolism, oxidative stress, and signal transduction. Annual Review of Plant Biology, vol. 55, p. 373399. PMid:15377225. http://dx.doi.org/10.1146/ annurev.arplant.55.031903.141701

AUGUSTYNOWICZ, J., MAREK GROSICKI, M., HANUS-FAJERSKA, E., LEKKA, M., WALOSZEK, A. and KOŁOCZEK, H. 2010. Chromium(VI) bioremediation by aquatic macrophyte Callitriche cophocarpa Sendtn. Chemosphere, vol. 79, no. 11, p. 1077-1083. PMid:20385400. http://dx.doi. org/10.1016/j.chemosphere.2010.03.019

BANCI, L., BERTINI, I., CIOFI-BAFFONI, S., D'ALESSANDRO, A., JAISWAL, D., MARZANOB, V., NERI, S., RONCI, M. and URBANI, A. 2011. Copper exposure effects on yeast mitochondrial proteome. Journal of Proteomics, vol. 74, no. 11, p. 2522-2535. PMid:21549866. http://dx.doi. org/10.1016/j.jprot.2011.04.014

BANDEOGLU, E., EYIDOGAN, F., YUCEL, M. and OKTEM, HA. 2004. Antioxidant responses of shoots and roots of lentil to $\mathrm{NaCl}$-salinity stress. Plant Growth Regulation, vol. 42, no. 1, p. 69-77. http://dx.doi. org/10.1023/B:GROW.0000014891.35427.7b

BATES, LS., WALDERN, RP. and TARE, ID. 1973. Rapid determination of free proline for water stress studies. Plant and Soil, vol. 39, no. 1, p. 205-207. http://dx.doi.org/10.1007/BF00018060

BEN HAMED, K., CASTAGNA, A., SALEM, E., RANIERI, A. and ABDELLY, C. 2007. Sea fennel (Crithmum maritimum L.) under salinity conditions: a comparison of leaf and root antioxidant responses. Plant Growth Regulation, vol. 53, no. 3, p. 185-194. http://dx.doi.org/10.1007/s10725-007-9217-8

Brasil. Ministério do Meio Ambiente. 2005. Resolução CONAMA no 357, de 17 de março de 2005. Dispóe sobre a classificação dos corpos de água e diretrizes ambientais para o seu enquadramento, bem como estabelece as condiçóes e padróes de lançamento de efluentes, e dá outras providências. Diário Oficial da Uniāo, Poder Executivo, Brasília, DF, 18 mar. 2005. p. 58-63.

BROWN, BT. and RATTIGAN, BM. 1979. Toxicity of soluble copper and other metal ions to Elodea canadensis. Environmental Pollution, vol. 20, no. 4, p. 303-314. http://dx.doi.org/10.1016/00139327(79)90153-8

DELMAIL, D., LABROUSSE, P., HOURDIN, P., LARCHER, L., MOESCH, C. and BOTINEAU, M. 2011. Differential responses of Myriophyllum alterniflorum DC (Haloragaceae) organs to copper: physiological and developmental approaches. Hydrobiologia, vol. 664, no. 1, p. 95-105. http:// dx.doi.org/10.1007/s10750-010-0589-9 
DHIR, B. and SRIVASTAVA, S. 2011. Heavy metal removal from a multi-metal solution and wastewater by Salvinia natans. Ecological Engineering, vol. 37, no. 6, p. 893-896. http://dx.doi.org/10.1016/j. ecoleng.2011.01.007

DUBOIS, M., GILlES, KA., HAMILTON, JK., REBERS, PA. and SMITH, F. 1956. Colorimetric method for determination of sugars and related substances. Analytical Qhemistry, vol. 28, no. 3, p. 350-356.

GRATÃO, PL., POLLE, A., LEA, PJ. and AZEVEDO, RA. 2005. Making the life of heavy-metal stressed plants a little easier. Functional Plant Biology, vol. 32, no. 6, p. 481-494. http://dx.doi.org/10.1071/ FP05016

GUIDA, M., INGLESEA, M. and MERIÇ, S. 2008. A multi-battery toxicity investigation on fungicides. Desalination, vol. 226, no. 1-3, p. 262-270. http:// dx.doi.org/10.1016/j.desal.2007.04.096

FU, F. and WANG, Q. 2011. Removal of heavy metal ions from wastewaters: a review. Journal of Environmental Management, vol. 92, no. 3, p. 407418. PMid:21138785. http://dx.doi.org/10.1016/j. jenvman.2010.11.011

HANIKENNE, M. and NOUET, C. 2011. Metal hyperaccumulation and hypertolerance: a model for plant evolutionary genomics. Current Opinion in Plant Biology, vol. 14, no. 3, p. 252-259. PMid:21531166. http://dx.doi.org/10.1016/j. pbi.2011.04.003

HEATH, RL. and PACKER, L. 1968. Photoperoxidation in isolated chloroplast: I. Kinetics and stoichiometry of fatty acid peroxidation. Archives of Biochemistry and Biophysics, vol. 125, no. 1, p. 189-198. PMid:5655425.

HU, C., ZHANG, L., HAMILTON, D., ZHOU, W., YANG, T. and ZHU, D. 2007. Physiological responses induced by copper bioaccumulation in Eichhornia crassipes (Mart.). Hydrobiologia, vol. 579, no. 1, p. 211-218. http://dx.doi.org/10.1007/ s10750-006-0404-9

HUGHES, JB., SHANKS, J., VANDERFORD, M., LAURITZEN, J. and BHADRA, R. 1996. Transformation of TNT by aquatic plants and plant tissue cultures. Environmental Science \& Technology, vol. 31, no. 1, p. 266-271.

JUAN, M., RIVERO, RM., ROMERO, L. and RUIZ, JM. 2005. Evaluation of some nutritional and biochemical indicators in selecting salt-resistant tomato cultivars. Environmental and Experimental Botany, vol. 54, no. 3, p. 193-201. http://dx.doi. org/10.1016/j.envexpbot.2004.07.004

KRIZEK, DT., BRITZ, SJ. and MIRECKI, RM. 1998. Inhibitory effect of ambient levels of solar UV-A and UV-B radiation on growth of cv. New Red Fire lettuce. Physiologia Plantarum, vol. 103, no. 1, p. 1-7. http://dx.doi.org/10.1034/j.13993054.1998.1030101.x
LEE, CL., WANG, TC., HSU, CH. and CHIOU, AA. 1998. Heavy metal sorption by aquatic plants in Taiwan. Bulletin of Environmental Contamination and Toxicology, vol. 61, no. 4, p. 497-504. PMid:9811955. http://dx.doi.org/10.1007/s001289900790

LIDON, FC. and HENRIQUES, FS. 1991. Limiting step on photosynthesis of rice plants treated with varying copper levels. Journal of Plant Physiology, vol. 138, no. 1, p. 115-118. http://dx.doi.org/10.1016/S01761617(11)80741-8

MAKSYMIEC, W., BEDNARA, J. and BASZYNSKI, T. 1995. Response of runner bean plants to excess copper as a function of plant growth stages: effects on morphology and structure of primary leaves and their chloroplast ultra-structure. Photosynthetica, vol. 31 , p. 427-435.

MEIRS, S., PHILOSOPH-HADAS, S. and AHARONI, N. 1992. Ethylene increased accumulation of fluorescent lipid peroxidation products detected during senescence of parsley by a newly developed method. Journal of the American Society for Horticultural Science, vol. 117, no. 1, p. 128-132.

MICHALAK, A. 2006. Phenolic compounds and their antioxidant activity in plants growing under heavy metal stress. Polish Journal of Environmental Studies, vol. 15 , no. 4 , p. 523-530.

MIGLIORANZA, KSB., MORENO, JEA. and MORENO VJ. 2004. Organochlorine pesticides sequestered in the aquatic macrophyte Schoenoplectus californicus (C.A. Meyer) Soják from a shallow lake in Argentina. Water Research, vol. 38, no. 7, p. 17651772. PMid:15026230. http://dx.doi.org/10.1016/j. watres.2004.01.017

MØLLER, IM., JENSEN, PE. and HANSSON, A. 2007. Oxidative modifications to cellular components in plants. Annual Review of Plant Biological, vol. 58, no. 1, p. 459-481. PMid:17288534. http://dx.doi. org/10.1146/annurev.arplant.58.032806.103946

MOORE, JW. 2011. Inorganic contaminants in surface water: research and monitoring priorities. London: Springer. 348 p.

NAHLIK, AM. and MITSCH, WJ. 2006. Tropical treatment wetlands dominated by free-floating macrophytes for water quality improvement in Costa Rica. Ecological Engineering, vol. 28, no. 3, p. 246-257. http://dx.doi.org/10.1016/j. ecoleng.2006.07.006

NOUET, C., MOTTE, P. and HANIKENNE, M. 2011. Chloroplastic and mitochondrial metal homeostasis. Trends in Plant Science, vol. 16, no. 7, p. 395-404. PMid:21489854. http://dx.doi.org/10.1016/j. tplants.2011.03.005

NÚÑEZ, SER., NEGRETE, JLM., RIOS, JEA., HADAD, HR. and MAINE, MA. 2011. Hg, Cu, $\mathrm{Pb}, \mathrm{Cd}$, and $\mathrm{Zn}$ accumulation in macrophytes growing in tropical wetlands. Water Air and Soil 
Pollution, vol. 216, no. 1-4, p. 361-373. http://dx.doi. org/10.1007/s11270-010-0538-2

MIRETZKY, P., SARALEGUI, A. and CIRELLI, AF. 2004. Aquatic macrophytes potential for the simultaneous removal of heavy metals (Buenos Aires, Argentina). Chemosphere, vol. 57, no. 8, p. 9971005. PMid:15488590. http://dx.doi.org/10.1016/j. chemosphere.2004.07.024

POLOMSKI, RF., TAYLOR, MD., BIELENBERG, DG., BRIDGES, WC., KLAINE, SJ. and WHITWELL, T. 2009. Nitrogen and phosphorus remediation by three floating aquatic macrophytes in greenhousebased laboratory-scale subsurface constructed wetlands. Water, Air, and Soil Pollution, vol. 197, no. 1-4, p. 223-232. http://dx.doi.org/10.1007/ s11270-008-9805-X

RAHMAN, MA. and HASEGAWA H. 2011. Aquatic arsenic: phytoremediation using floating macrophytes. Chemosphere, vol. 83, no. 5, p. 633646. PMid:21435676. http://dx.doi.org/10.1016/j. chemosphere.2011.02.045

RAUSER, WE. 1999. Structure and function of metal chelators produced by plants: the case for organic acids, amino acids, phytin, and metallothioneins. Cell Biochemistry Biophysics, vol. 31, no. 1, p. 1948. PMid:10505666. http://dx.doi.org/10.1007/ BF02738153

ROBYT, IF. and WHITE, JB. 1987. Biochemical techniques: theory and practice. Monterey: Brooks and Cole Publishing. 407 p.

RODGERS JD. and BUNCE, NJ. 2001. Treatment methods for the remediation of nitroaromatic explosives. Water Research, vol. 35, no. 9, p. 2101-2111. http://dx.doi.org/10.1016/S00431354(00)00505-4

SAADALLAH, K., DREVON, JJ. and ABDELLY, C. 2001. Nodulation et croissance nodulaire chez le haricot (Phaseolus vulgaris) sous contrainte saline. Agronomie, vol. 21, no. 6-7, p. 627-634. http:// dx.doi.org/10.1051/agro:2001154

SAKIHAMA, Y., COHEN, MF., GRACE, SC. and YAMASAKI, H. 2002. Plant phenolic antioxidant and prooxidant activities: phenolics-induced oxidative damage mediated by metals in plants. Toxicology, vol. 177, no. 1, p. 67-80. http://dx.doi. org/10.1016/S0300-483X(02)00196-8

SALOMONS, W., FORSTNER, U. and MADER, P. 1995. Heavy metals: problems and solutions. Berlin: Spring Publishing. 412 p.

SCULTHORPE, CD. 1967. The biology of aquatic vascular plants. London: William Glove \& Sons. $610 \mathrm{p}$.

SHAH, K. and DUBEY, RS. 1998. Effect of cadmium on proline accumulation and ribonuclease activity in rice seedlings: role of proline as a possible enzyme protectant. Biologia Plantarum, vol. 40, no. 1, p. 121130. http://dx.doi.org/10.1023/A:1000956803911

SHARMA, SS., SCHAT, H. and VOOIJS, R. 1998. In vitro alleviation of heavy metal-induced enzyme inhibition by proline. Phytochemistry, vol. 49, no. 6, p. 1531-1535. http://dx.doi.org/10.1016/S00319422(98)00282-9

SINGH, V., BHATT, I., AGGARWAL, A., TRIPATHI, BN., MUNJAL, AK. and SHARMA, V. 2010. Proline improves copper tolerance in chickpea (Cicer arietinum). Protoplasma, vol. 245, no. 1-4, p. 173181. PMid:20625778. http://dx.doi.org/10.1007/ s00709-010-0178-9

SOLAND, SF. and LAIMA, SK. 1999. Phenolics and cold tolerance of Brassica napus. Plant Agriculture, vol. 1, p. 1-5.

SOLANKI, R. and DHANKHAR, R. 2011. Biochemical changes and adaptive strategies of plants under heavy metal stress. Biologia, vol. 66, no. 2, p. 195-204. http://dx.doi.org/10.2478/s11756-011-0005-6

SOLECKA, D. 1997. Role of phenylpropanoid compounds in plant responses to different stress factors. Acta Physiologiae Plantarum, vol. 19, no. 3, p. 257-268. http://dx.doi.org/10.1007/s11738997-0001-1

SONG, L., MARSH, TL., VOICE, TC. and LONG, DT. 2011. Loss of seasonal variability in a lake resulting from copper sulfate algaecide treatment. Physics and Chemistry of the Earth, Parts $A / B / C$, vol. 36, no. 9-11, p. 430-435. http://dx.doi.org/10.1016/j. pce. 2010.04 .016

STOBART, AK., GRIFFIHS, WT. and AMEENBUKHARI, I. 1985. The effects of $\mathrm{Cd} 2+$ on the biosynthesis of chlorophyll in leaves of barley. Physiologia Plantarum, vol. 63, no. 3, p. 293-298. http://dx.doi.org/10.1111/j.1399-3054.1985. tb04268.x

WANGER, GJ. 1979. Content and vacuole/extra vacuole distribution of neutral sugars, free amino acids, and anthocyanins in protoplast. Plant Physiology, vol. 64, no. 1, p. 88-93. PMid:16660921 PMCid:PMC543030. http://dx.doi.org/10.1104/ pp.64.1.88

WELLBURN, AR. 1994. The spectral determination of chlorophylls a and b, as well as total carotenoids, using various solvents with spectrophotometers of different resolution. Journal of Plant Physiology, vol. 144, no. 3, p. 307-313. http://dx.doi.org/10.1016/S01761617(11)81192-2

YRUELA, I. 2005. Copper in plants. Brazilian Journal of Plant Physiology, vol. 17, no. 1, p. 145-146. http:// dx.doi.org/10.1590/S1677-04202005000100012 